\title{
Natural Resources, Human Capital and Economic Growth: Evidence from Indonesia
}

\author{
Dewi Rahayu ${ }^{1}$ \\ \{dewirahayu@ulm.ac.id ${ }^{1}$ \} \\ Department of Economics and Development Studies, Lambung Mangkurat University, Indonesia ${ }^{1}$
}

\begin{abstract}
Empirical evidence indicates that natural resource abundance contributes significantly to economic growth in natural resource-rich countries. Meanwhile, the literature on economic growth demonstrates that human capital is a significant factor in economic growth. This article examines the relationship between Indonesia's natural resource abundance, human capital, and economic growth. The article examined the impact of natural resource and human capital on economic growth in Indonesian provinces using panel data from 2015 to 2019. The findings indicate that natural resources have a detrimental effect on economic growth. This indicates that Indonesia's natural resourcerich provinces are also suffering from the natural resource curse. Several of natural resource-rich provinces have low human capital and high poverty rates. Local Governments must reduce dependence on natural resources and shift the economy to a more productive and sustainable sectors.
\end{abstract}

Keywords: Natural Resource, human capital, economic growth, natural resources curse hypothesis

\section{Introduction}

The growth patterns and levels of regional disparities in development that are found in several provinces in Indonesia are not merely due to differences in per capita GRDP developments between provinces, but are also related to many aspects, especially differences in resources and their demographic characteristics. According to [1], factors that cause disparities between regions in Indonesia include the concentration of regional economic activity, investment allocation, the level of mobility of production factors between regions, differences in natural resource ownership (SDA), differences in geographical conditions between regions, and lack of smooth trade between provinces due to inadequate infrastructure.

Natural resources, as demonstrated by experience in countries such as the United States and the United Kingdom, play a minor role in their development. On the other hand, another example from the Asian economic experience called the Asian Tiger which does not have the gift of natural resources, but is able to achieve high levels of economic growth. Just as South Korea, which was poor in natural resources and experienced a shortage at the start of its development, after the Korean War ended in 1953, it could quickly produce an impressive economic performance with a high average growth rate per year [1].

Natural resource wealth owned by a country is often considered a blessing that can help the country become economically rich. However, empirical economic research has discovered an ironic phenomenon known as the "natural resource curse," which states that countries with 
abundant natural resources typically experience slower economic growth than countries with scarce natural resources.

This paradox was first put forward by [2] and corroborated by [3]. This can clearly be seen by comparing the GDP per capita of natural resource-rich countries in Asia Pacific such as Indonesia, the Philippines, Myanmar and Papua New Guinea which lag behind countries with very limited natural resources, such as Singapore, Japan and South Korea.

According to [4], the role of natural resources in regional development is a point of contention between the dependency and comparative advantage theories. Natural resources, according to dependency theory, impede development, whereas comparative advantage theory asserts that natural resources can accelerate development. Since the publication of [3], there has been debate over the so-called natural resource curse hypothesis, according to which countries endowed with natural resources perform worse economically than countries endowed with few natural resources.

The empirical evidence for the resource curse paradox is mixed. While some of them corroborate Sachs and Warner's findings (e.g. [5][6][7]), others cast doubt on the natural resource curse paradox's validity (e.g. [8][9][10]). According to [10], the model of the effect of natural resource abundance on economic growth has not been completely satisfactory, despite the possibility that natural resources may have a more positive effect on economic growth than is typically assumed. Additionally, [10] stated that the theoretical explanation should incorporate the institutional role in the growth process.

[11] conducted research on the impact of natural resources on economic growth in Indonesia at the district / city level, and [12] at the provincial level. These two studies indicate that natural resources contribute to regional economic growth. Meanwhile, research [13] conducted at the provincial level in Indonesia and [14] conducted at the district/city level in Kalimantan indicates that natural resources have a detrimental effect on economic growth.

Additionally, the empirical evidence on the impact of human capital on economic growth is mixed. Among them, the findings of [15], [16], and [17] demonstrated the beneficial effects of human capital on growth. Meanwhile, [18] and [19] discovered that human capital stock was insignificant, if not negative.

The difference in results regarding the role of human capital on economic growth is more due to measurements that cannot be carried out directly. Each researcher must use a proxy for measuring both natural resources and human capital. This is as stated by [20], empirical research has not produced convincing results to confirm its importance for economic growth. According to them, the main problem lies in how to build the human capital variable, which is not measured directly.

The preceding opinion is consistent with that expressed by [21], who asserts that quantifying human capital is more difficult to comprehend than defining it. Numerous authors have included stages of formal education, such as enrollment or educational attainment, while others have been forced to use indirect proxies such as literacy and mathematics to identify human capital.

Along with the different proxies used by researchers to measure human capital, the methods used to examine the effect of human capital on growth vary as well. According to empirical studies conducted by [22] and [17], using primary and secondary school enrollment rates, human capital has a positive and significant effect on growth. Likewise [23] empirical study of 100 countries for the period 1960 - 1995, which includes measures that differentiate human capital not only by level of education but also by sex. On the other hand, [18] and [19] found insignificant or even negative results for human capital stock, i.e. mean total years of schooling. 
As a result of the preceding description, one can conclude that empirical research on the role of natural resources and human capital in economic growth continues to yield inconsistent findings. These seemingly contradictory findings may be explained by intangible variables associated with natural resources and human capital, as well as by the use of disparate methods for analyzing the relationship between human capital and growth. As a result, the role of natural resources and human capital in economic growth continues to be an enticing area of study. This study sought to quantify the economic impact of natural resources and human capital.

\section{Method}

This study makes use of secondary data from the Central Bureau of Statistics and the Ministry of Finance's Directorate General of Fiscal Balance. Economic Growth (EG), Gross Regional Domestic Product (GRDP), Gross Regional Domestic Product Per Capita (GRDPCap), Natural Resource Profit Sharing Funds (SNR), Mean Year School (MYS), Labor, Domestic Investment (DI), and Foreign Investment are all collected data (FI). All variables are converted in natural logarithm.

The method used to estimate the effect of natural resources and human capital is panel data, involving all provinces in Indonesia except Bali province in the period 2015 - 2019. Bali Province is not included as the area studied because it does not have a share of natural resources as a measure for natural resources in this study. The Equation Model as follow:

$$
\text { Growth }_{i t}=\beta_{0, i t}+\beta_{1} \text { GRDPCap }_{i, t-1}+\beta_{2} \text { SNR }_{i t}+\beta_{3} M Y S_{i t}+\beta_{4} \text { Labor }_{i t}+\beta_{5} D I_{i t}+\beta_{6} F I_{i t}
$$

Following the Chow and Hausman tests, panel regression and FEM (Fixed Effect Model) were used to determine the best model among the Common Effect, Fixed Effect, and Random Effect models (REM).

\section{Results and Discussions}

\subsection{Estimation results}

After doing the Chow test, it showed that FEM was better than Common Effect and Hausman test indicating that FEM was better than REM. So that it can be further analyzed is the FEM model.

Table 1 shows that the previous year's GRDPCAP had a negative and significant effect, this shows that rich provinces experienced lower growth compared to other regions. Based on the theory of neo-classical economic growth, this is known as convergence. 
Table 1. Estimation Result of Fixed Effect Model

\begin{tabular}{cl}
\hline Variable & Coefficient \\
\hline Constant & -23.39061 \\
GRDPCap $i, t-1$ & $-23.33631^{* * *}$ \\
SNR $_{i t}$ & -0.280040 \\
MYS $_{i t}$ & $8.804187^{*}$ \\
Labor $_{i t}$ & $17.40377^{* *}$ \\
DI & 0.113822 \\
FI $_{i t}$ & 0.527733 \\
\hline Obs: & 165 \\
F-Test : & $2.8287 * * *$ \\
R-Squared: & 0.4604 \\
Adj R-Squared: & 0.2976 \\
\hline *** Statistically significant at alpha $1 \%, * * 5 \%$ and * $10 \%$ \\
\hline
\end{tabular}

SNR shows a negative but insignificant effect, while MYS shows a positive and significant effect, as well as Labor. This suggests that the resource curse is also experienced by some provinces in Indonesia.

\subsection{Discussion}

In Figure 1, we can see that in Indonesia, several provinces with abundant natural resources experience lower economic growth than other provinces. In 2015, East Kalimantan Province, which had the highest natural resources, experienced negative economic growth, namely -1.20 percent, as well as Riau Province which only experienced economic growth of 0.22 percent. Meanwhile, the rich natural resources province that still has high economic growth is Central Sulawesi, namely 15.5 percent in 2015 .



Fig. 1. Economic Growth and Share of Natural Resources, 2015 
In 2019, the economic growth of East Kalimantan Province improved with a growth rate of 4.77 percent. In fact, Papua Province has experienced a very sharp decline in economic growth, with an economic growth rate of -15.72 percent. There are show in Figure 2.
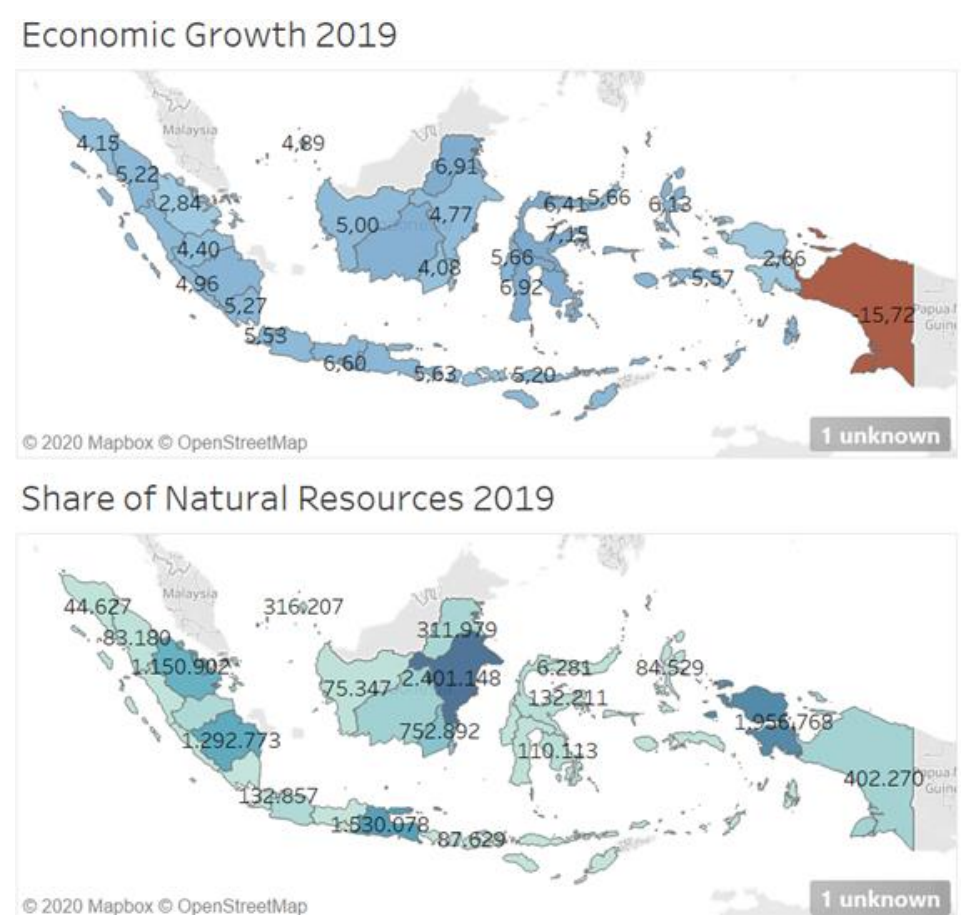

Fig. 2. Economic Growth and Share of Natural Resources, 2019

The socio-economic conditions in some natural resource-rich provinces are lower than in those without natural resources. High poverty rates in natural resource-rich provinces. Human Development Index (HDI) is still lower than the national level, except for East Kalimantan and Riau. Several natural resource-rich provinces experienced high unemployment rates, especially East Kalimantan, which showed the highest unemployment rate among natural resource-rich provinces. The Gini Ratio still shows a lower level than the national level except for Southeast Sulawesi and Papua, which are slightly higher than the national one, which means that the inequality between community income groups is relatively the same Table 2 .

Table 2. Socio-Economic Conditions in 10 Natural Resource-Rich Provinces in Indonesia

\begin{tabular}{lcccc}
\hline \multirow{2}{*}{ Province } & \multicolumn{4}{c}{ Mean $(\mathbf{2 0 1 5}-\mathbf{2 0 1 9})$} \\
\cline { 2 - 5 } & Poverty (\%) & IPM & Unemployment (\%) & Gini Ratio \\
\hline East Kalimantan & 6.00 & 75.26 & 7.20 & 0.33 \\
Papua & 27.60 & 59.06 & 3.60 & 0.40 \\
Jambi & 8.20 & 70.08 & 4.00 & 0.34 \\
Riau & 7.60 & 71.85 & 6.60 & 0.34 \\
North Kalimantan & 6.60 & 69.90 & 5.20 & 0.30 \\
West Nusa Tenggara & 15.40 & 66.60 & 4.00 & 0.37 \\
South East Sulawesi & 12.20 & 69.95 & 3.80 & 0.40
\end{tabular}




\begin{tabular}{lrrrr} 
Central Sulawesi & 13.80 & 68.14 & 3.40 & 0.35 \\
West Sulawesi & 11.20 & 64.34 & 3.00 & 0.36 \\
South Kalimantan & 4.80 & 69.59 & 4.80 & 0.34 \\
\hline Nasional & $\mathbf{1 0 . 2 0}$ & $\mathbf{7 0 . 7 7}$ & $\mathbf{5 . 6 0}$ & $\mathbf{0 . 3 9}$ \\
\hline
\end{tabular}

\section{Conclusion}

The previous year's GRDP per capita had a negative impact on economic growth, which means that the hypothesis regarding convergence occurs in the provinces of Indonesia. This shows that rich provinces experience lower growth than low-income per capita provinces. Several provinces with abundant natural resources experience lower economic growth than other provinces, especially East Kalimantan and Riau in 2015. In 2019, the economic growth of East Kalimantan Province improved with a growth rate of 4.77 percent. In fact, Papua Province has experienced a very sharp decline in economic growth, with an economic growth rate of 15.72 percent. Natural resources have a negative effect on economic growth, albeit a negligible one. Human capital has a significant positive effect. Local governments must diversify their economic base away from natural resources and toward more productive and sustainable sectors.

\section{Acknowledgment}

Thanks are given to the Faculty of Economics and Business, University of Lambung Mangkurat who has provided funding for this research.

\section{References}

[1] T. T. H. Tambunan, Perekonomian Indonesia: Beberapa Permasalahan Penting. Bogor: Ghalia Indonesia, 2003.

[2] R. M. Auty, "The political economy of resource-driven growth,” Eur. Econ. Rev., vol. 45, pp. 839$846,2001$.

[3] J. D. Sachs and A. M. Warner, "Natural Resource Abundance and Economic Growth," NBER Work. Pap., vol. 3, no. 5398, pp. 1-54, 1995.

[4] T. Gunton, "Natural Resources and Regional Development: An Assessment of Dependency and Comparative Advantage Paradigms," Econ. Geogr., vol. 79, no. 1, pp. 67-94, 2003.

[5] T. Gylfason, "Natural Resources, Education, and Economic Development," Eur. Econ. Rev., vol. 45, pp. 847-859, 2001.

[6] J. C. Stijns, "Natural Resource Abundance and Economic Growth Revisited," Resour. Policy, vol. 30, pp. 107-130, 2005, doi: 10.1016/j.resourpol.2005.05.001.

[7] N. Ding and B. C. Field, "Natural Resource Abundance and Economic Growth," Land Econ., vol. 81, no. 4, pp. 496-502, 2005.

[8] T. V. D. V. Cavalcanti, K. Mohaddes, and M. Raissi, "Growth, development and natural resources: New evidence using a heterogeneous panel analysis," Q. Rev. Econ. Financ., vol. 51, no. 4, pp. 305 318, Nov. 2011, doi: 10.1016/j.qref.2011.07.007.

[9] Q. M. A. Hye and M. M. Siddiqui, "Economic Growth and Management of Natural Resources in the Case of Pakistan,” Eur. J. Econ. Financ. Adm. Sci., vol. 22, no. 22, pp. 94-101, 2010. 
[10] C. N. Brunnschweiler, "Cursing the Blessings ? Natural Resource Abundance, Institutions, and Economic Growth," World Dev., vol. 36, no. 3, pp. 399-419, 2008, doi: 10.1016/j.worlddev.2007.03.004.

[11] A. Komarulzaman and A. S. Alisjahbana, "Testing the Natural Resource Curse Hypothesis in Indonesia : Evidence at the Regional Level,” Work. Pap. Econ. Dev. Stud., no. 200602, 2006.

[12] D. Prasasti, "Perkembangan Produk Domestik Regional Bruto per Kapita 30 Provinsi di Indonesia Periode 1993-2003: Pendekatan Disparitas Regional dan Konvergensi,” J. Ekon. dan Bisnis Indones., vol. 21, no. 4, pp. 344-360, 2006.

[13] D. Rahayu and Munawar, "The Role of Natural Resources and Human Capital on Economic Growth in Indonesia," in Regional Development, Natural Resources and Public Goods in Indonesia During the Global Financial Crisis, vol. XI, 2013, pp. 33-53.

[14] D. Rahayu, M. Ismail, D. B. Santoso, and D. S. Pratomo, "Do Natural Resources and Human Capital Matter to Regional Income Convergence? (A Case Study at Regencies/Municipalities of Kalimantan Area - Indonesia)," Procedia - Soc. Behav. Sci., vol. 211, pp. 1112-1116, 2015, doi: 10.1016/j.sbspro.2015.11.148.

[15] R. E. Lucas, “On the Mechanics of Economic Development," J. Monet. Econ., vol. 22, no. February, pp. 3-42, 1988.

[16] R. J. Barro, "Economic Growth in a Cross Section of Countries.," Q. J. Econ., vol. 106, no. 2, pp. 407-443, 1991, doi: 10.2307/2937943.

[17] N. G. Mankiw, D. Romer, and D. N. Weil, "A Contribution to the Empirics of Economic Growth," Q. J. Econ., vol. 107, no. 2, pp. 407-437, 1992.

[18] J. Benhabib and M. M. Spiegel, "The Role of Human Capital in Economic Development Evidence from Aggregate Cross-Country Data,” J. Monet. Econ., vol. 34, no. 2, pp. 143-173, 1994, doi: 10.1016/0304-3932(94)90047-7.

[19] G. A. Kyriacou, "Level and Growth Effects of Human Capital: A Cross-Country Study of the Convergence Hypothesis," Econ. Res. Reports, vol. 91, no. 26, 1991.

[20] S. Maksymenko and M. Rabbani, "Economic Reforms, Human Capital, and Economic Growth in India and South Korea: A Cointegration Analysis," J. Econ. Dev., vol. 36, no. 2, pp. 39-59, 2011.

[21] L. P. de la Escosura and J. R. Rosés, "Human Capital and Economic Growth in Spain, 1850 - 2000," Explor. Econ. Hist., vol. 47, pp. 520-532, 2010, doi: 10.1016/j.eeh.2010.02.002.

[22] R. J. Barro, "Human Capital and Growth," Am. Econ. Rev., vol. 91, no. 2, pp. 12-17, 2001.

[23] R. J. Barro, "Human Capital and Growth in Cross-Country Regressions," Swedish Econ. Policy Rev., vol. 6, no. 2, pp. 237-277, 1999, doi: 10.1787/750033432084. 